\title{
The Investigating of Influencing Factors on Customer Loyalty Outcomes in Myanmar Private Bank: The Corporate Social Responsibility (CSR) and Corporate Image Perspectives
}

\author{
Pyae Phyo Aung ${ }^{*}$ and Phanasan Kohsuwan
}

International College, Panyapiwat Institute of Management, Nonthaburi 11120, Thailand

*Corresponding author. E-mail: pppyae1988@gmail.com

https://doi.org/10.12982/CMUJASR.2019.0001

\begin{abstract}
The study aimed to analyze the impact of corporate social responsibility (CSR) and corporate image on customer loyalty and to examine the relationship between customer loyalty and loyalty outcomes of banking customers in Myanmar. This study focused on stakeholder CSR approach and corporate image as predictors of loyalty, leading to loyalty outcomes. The quantitative research was used with structured questionnaires, and with convenience sampling, 500 valid responses of banking customers were applied for data analysis by using a structural equation model. The results indicated that CSR and corporate image affected customer loyalty and customer loyalty had positive relationships with five loyalty outcomes of banking customers. The findings could contribute to the service loyalty context in the aspect of stakeholder CSR and corporate image, including loyalty outcomes. Moreover, the findings could be applied to the development of CSR and corporate image strategies to retain banking customers, especially for private banks in Myanmar.
\end{abstract}

Keywords: Corporate Social Responsibility (CSR), Corporate image, Customer loyalty, Loyalty outcomes, Myanmar Private Banks

\section{INTRODUCTION}

The banking sector has faced intense competition all over the world, and banks are now focusing on the loyal condition of customers to gain a competitive advantage in the industry (Leninkumar, 2017). Loyalty is a critical outcome produced by what the consumers faced with a bank. (Keisidou et al., 2013, Seiler et al., 2013 ). Because customer loyalty is vital for strategic and economic aspects, examining customer loyalty and exploring the antecedents of customer loyalty in the banking sector has captured the interest of many researchers (Valipour et al., 2018). While most researches in the loyalty context were done by emphasizing the repurchase behavior of products, the loyalty aspect for the service field was also significant ( $\operatorname{Rad}$ et al., 2017). Differentiating the firms based on products and service attribute is not practical to get competitive advantage so that loyal customer becomes the primary source of competitive advantage in competing with other counterparts (Kandampully et al., 2015).

Focusing on loyal customers may be a challenging objective, but it can decrease costs and increase profitability (Homburg et al., 2011). Customer loyalty helps companies to achieve a competitive advantage in the market, and by having loyal customers, companies have lower costs, 
higher sales, and increased profit (Yunus et al., 2012). Building and sustaining customer's loyal condition enabled firms to build up mutual relationship with customers that can benefit both firms and customers in the long run (Pan et al., 2012); these loyal customers exhibit attachment and commitment toward the company and are not attracted to competitors' offerings (So et al., 2013). Furthermore, loyal customers do not take much consideration on prices and want to pay more and describe themselves as they have more purchase intentions and do not switch to other competing firms easily (Evanschitzky et al., 2012).

With considerable progress and significant credit growth within a few years, the Myanmar banking sector was experienced with needed transformation in 2017 and 2018 (Oxford Business Group, 2019). The banking industry in Myanmar has undergone tremendous and continuous growth over the last decade with the latest new products and practices. Due to fierce competition, especially from non-bank and changed legislation, the banks have lost their market share in the domestic field (Ali et al. 2014). Faced with this challenging environment, building and maintaining customer loyalty is vital for the banks as it has a significant effect on the business condition, such as the amount of deposited money, cost of operation, and marketing and customer retention rates (Bakar et al., 2017). Many studies showed CSR as the predictors of customer loyalty, and recent ones practically described a positive relationship between CSR and customer loyalty (Butcher \& Chomvilailuk, 2014). Many studies have undertaken in terms of CSR and its impact on consumer/customer behavior (Fatma et al., 2014). Domestic firms become more aware of CSR as same as international firms in Myanmar do although their implementing CSR activities are different from those of international peers (Barkemeyer \& Miklian, 2019). The top four firms for doing CSR activities in Myanmar include the two business groups that are doing in the banking industry (Minyin, 2018) so that it can be concluded that most major banks focus on CSR practices as their marketing tools. One study done by Iqbal and Pramanik (2017) in Bangladesh - a developing country- showed that CSR activities had an impact on customer loyalty of banking customers. However, it seems the studies done in Myanmar, concerning CSR are very few compared to other countries. Therefore, it is very vital to fill this gap by researching to explore the impact of CSR practices on customer loyalty.

Customer loyalty could be generated by reinforcing a positive company image (Gioia et al., 2000). Moreover, several researchers also proved that corporate image had a positive influence on customer loyalty (Wang \& Chaipoopirutana, 2014). Due to the fierce competitive condition of the market and the rapid development of the service sector, firms need to differentiate themselves from others with the corporate image (Liat et al., 2017). The customers take a significant consideration of the corporate image of the companies before they purchase products or services from these companies (Telagawathi et al., 2018). In addition, few studies proved that include image as loyalty determinants in examining bank loyalty (Bakar et al., 2017). One study in India showed that corporate image was a predictor of customer loyalty in the banking sector (Singh et al., 2019). Moreover, studying corporate image context in Myanmar is rare. Therefore, it is needed to fill this gap by doing this study - the impact of corporate image on customer loyalty of banking customers in Myanmar.

Two factors predicted customer loyalty, namely, CSR activities and corporate image, leading to loyalty outcomes in the study. According to Turker (2009), there were four stakeholder CSR social and non-social CSR, customer CSR, employee CSR, and government CSR. Regarding corporate image, there were six dimensions - reputation of directors, service offering, contact 
personnel, corporate identity, access to service, and physical environment (Nguyen, 1996). To be specific, the research objectives were as follows:

(1) To examine the relationship between CSR activities and Customer Loyalty of bank customers in Myanmar.

(2) To explore the relationship between corporate image and Customer Loyalty of bank customers in Myanmar.

(3) To analyze the relationship between customer loyalty and loyalty outcomes of bank customers in Myanmar.

\section{LITERATURE REVIEW}

\section{Customer loyalty and Loyalty outcomes}

Loyal customers purchase products or services again, and they advocate a company to other people, and they are attached to a business over time (Prus \& Brandt, 1995). Oliver (1999) stated that loyalty is a deeply held commitment to re-purchase or re-patronize a preferred product/service constantly in the future, thereby enabling repetitive purchasing on the same brand, although situational factors and marketing activities may enable switching behavior.

The characteristics of services offered, ways of communication with a customer, the level of customization, and means of service distribution are critical in forming customer loyalty for a bank (Javalgi \& Moberg, 1997). Customer loyalty for the banking services is characterized by staying and getting services with the same bank, purchasing different kinds of services, and the frequency of service usage (Lewis \& Soureli, 2006).

Loyalty is primarily valued for its outcomes since it is the outcome behavior of loyal customers that have a significant influence on the income and development of a business (Rai \& Srivastava, 2014). Jones and Taylor (2007) argued that advanced literature had proposed loyalty to be a three-dimensional construct as the outcomes of loyalty can broadly be categorized as behavioral, attitudinal, and cognitive loyalty. The behavioral loyalty emphasized customers' manner characteristics that they showed actually without considering their beliefs and preferences so that a loyalty customer is one who practically purchases products or services from a company and keeps purchasing from that company in the future (Rai \& Srivastava, 2014). Attitudinal Loyalty is related to customers' positive attitude about products and services they purchased and try to encourage others to purchase and use them by advocating others (Chaudhari \& Holbrook, 2001). Cognitive loyalty is based on a customer's emotional preference to a brand, including a positive attitude about a continuous purchase from a brand (Härtel \& Russell-Bennett, 2010).

\section{Corporate Social Responsibility (CSR)}

From a general perspective, CSR can be regarded as businesses' involvement in improving social well-being through discretionary business activities and commitments by applying their resources possessed (Kotler \& Lee, 2005). Banks can contribute to the welfare of society and the well-being of the environment in term of CSR by avoiding business activities that can harm society and the environment in doing investment and financing functions and ensuring their service offering process that can promote social equality and encourage green environment (Castelo, 2013).

CSR is described as corporate behaviors that purpose to have a positive effect on stakeholders rather than economic interest. CSR is closely related to the concept of stakeholders. Stakeholders of a firm include those who affect or are affected by the firm's goals (Freeman, 1984). In measuring 
CSR, the literature provides three primary approaches for the researchers. The first approach includes four components of CSR - economic, legal, ethical, and discretionary or philanthropic (Carroll, 1979). A second one is related to the aspect of social responsibility and sustainable development (Kolk \& Tulder, 2010). Measuring under this approach, CSR consists of three factors - economic, environmental, and social. Finally, the third approach of CSR was based on stakeholder view, concerning corporate responsibilities towards particular stakeholder categories: shareholders, customers, employees, the environment, the society, and others (Freeman et al., 2010)

\section{Corporate image}

Image is the overall impression stacked in the minds of customers (Dichter, 1985). It is associated with custom, belief, business identity, reputation, different kinds of services, and to the perception of quality delivered by each person (Solomon, 1985). The image consists of two primary components: functional and emotional (Kennedy, 1977). The functional component is associated with the tangibility of the product or services that can be evaluated quickly, while the emotional component is related to the psychological aspect, concerning belief and thought towards a firm. These feelings are sourced from personal past experiences with a firm and based on the information processed through attributes of functional parts of the image. Corporate image is the outcome of an aggregate procedure by which customers evaluate various characteristics of companies. A set of six factors were identified in the literature as having the potential of influencing customer perceptions of corporate image in service firms (Nguyen, 1996). These factors are corporate identity, reputation, service offering, physical environment, contact personnel, and access to services.

Management of financial firms takes emphasis on corporate image because it results in unique competitive advantage, but it cannot be achieved in the short run (Hall, 1993) and it creates barriers to entry for new businesses to the financial market (Flavián et al., 2005). Corporate image influences the behavioral aspect of potential customers and that of other interest groups that tend to be successful (Balmer et al., 2001).

Loyalty is a process of mental condition that is primarily appreciated and recognized through behavioral characteristics, and it reflects a feeling, or an attitude of enduring attachment induced by affection (Rai \& Srivastava, 2014). CSR can be defined as businesses' involvement in improving society's interest with optional firm activities and commitments by applying their assets possessed (Kotler \& Lee, 2005). Corporate image is the description of a firm's personality that leads to gain a unique view from the customer's perception (Schmitt \& Pan, 1994; Melewar, 2008). Many studies showed that CSR as the predictors of customer loyalty (Pérez et al., 2013; Butcher \& Chomvilailuk, 2014) and the image of a company has a positive direct impact on the condition of customer loyalty (Makanyeza \& Chikazhe, 2017).

\section{Research hypotheses}

Based on the facts described in the literature review, the study intended to analyze the impact of CSR and corporate image on customer loyalty and to examine the relationship between customer loyalty and loyalty outcomes. Many past researches were done, focusing on the impact of CSR on customer loyalty directly. According to Lee (2018), Customer loyalty is one of the primary behaviors of customers that firms desire to cultivate through the use of CSR as a marketing tool. Some researches questioned the relationship between CSR activities and customer loyalty or consumer behavior that were intended for the future (Lombart \& Louis, 2014). However, several 
studies found that CSR had a direct impact on customer loyalty (Ailawadi et al., 2014; Chung et al., 2015) and the relationship between CSR and customer loyalty was also founded among banking customers (Butcher \& Chomvilailuk, 2014). From the above discussion, the following hypothesis was proposed;

$\mathrm{H}_{1}$ : CSR will have a positive influence on Customer Loyalty.

Past studies revealed that the Corporate image had an impact on customer loyalty (Dick \& Basu, 1994; Andreassen \& Lindestad, 1998). If customers believed that a company had a positive image and offered more values than other competitors, their loyalty toward that company remained in the long run (Ibáñez et al., 2006). It was understood that a good corporate image influences the growth of customer loyalty, influencing the latter to buy products continuously (Mokhtar et al., 2011). A high level of customer loyalty was sourced from a positive and strong corporate image (Greve, 2014). The loyal condition toward the brand reminded in the mind of customers for a long time because the customer's belief in a firm was caused by the good image of that firm (Osman et al., 2015). Previous studies also showed that a relationship between corporate image and customer loyalty existed in the banking sector (Lewis \& Soureli, 2006; Darmawan et al., 2017).

From the above discussion, the following hypothesis was proposed;

$\mathrm{H}_{2}$ : Corporate image will have a positive influence on Customer Loyalty.

According to Rai and Srivastava (2012), outcomes of behavioral loyalty included repatronage intention, resistance to change, share of wallet (exclusive purchasing) and outcomes of attitudinal loyalty consist of the strength of preference, advocacy (willingness to refer), altruism. Also, outcomes of cognitive loyalty were price indifference (price insensitivity), exclusivity (top of mind) and identification. In the study, five loyalty outcomes - identification, exclusivity, advocacy, the strength of preference, and share of wallet - were applied according to Bourdeau (2005). A study in Myanmar private banking showed that customer loyalty was a predictor of five loyalty outcomes - identification, exclusivity, advocacy, the strength of preference and share of wallet (Myint \& Kohsuwan, 2019). Identification is the relationship developing between customer and service firm causes a feeling of ownership over that firm, indicating as a sense of my own firm (Gabbott \& Hogg, 1994; Bhattacharya et al., 1995; Butcher et al., 2001) Exclusivity is the magnitude of the consideration from the consumer over the service firm as the first one in purchasing a specific category of service (Dwyer et al., 1987; Jones \& Taylor, 2007; Rai, 2013). Advocacy is a consumer's desire to advocate a service firm to others (Westbrook, 1987; Dick \& Basu, 1994; Rai, 2013). Strength of preference is the preference that depends on the attitudinal condition of loyalty, consisting of an emotional comparison of products or services (Day, 1969; Dick \& Basu, 1994; Oliver, 1999; Butcher et al., 2001). Share of wallet is a customer's sincere willingness to do a huge amount of purchases of a particular variety with the only one service firm (Day 1969; Reynolds \& Beatty 1999).

From the above discussion, the following hypotheses were proposed;

$\mathrm{H}_{3 \mathrm{a}}$ : Customer loyalty will have a positive influence on customer identification.

$\mathrm{H}_{3 \mathrm{~b}}$ : Customer loyalty will have a positive influence on Exclusive Consideration.

$\mathrm{H}_{3 \mathrm{c}}$ : Customer loyalty will have a positive influence on Advocacy.

$\mathrm{H}_{3 \mathrm{~d}}$ : Customer loyalty will have a positive influence on customer Preference.

$\mathrm{H}_{3 \mathrm{e}}$ : Customer loyalty will have a positive influence on Share of wallet. 


\section{RESEARCH METHODOLOGY}

Exploratory and descriptive research was used in the study. Based on previous studies, a drafted questionnaire was prepared, and this questionnaire was adjusted and edited according to Item Objective Congruence (IOC) test result. In order to do a pilot test, the questionnaire was translated from English to Myanmar using the back-translation technique. The pilot test was conducted using 30 samples. Based on the results of the pilot test, the final questionnaire was prepared for primary data collection by making some adjustments to the scale items such as "The schedule of the Bank is good." into "The operating time of the Bank is convenient for me." In 2016, the number of bank accounts was 25.1 million (World Bank, 2018), and this number was the target population of the study. Six hundred respondents who are bank customers from Mandalay were surveyed with a structured questionnaire by using convenience sampling. After removing incomplete responses and outliners, 500 valid responses were used for data analysis and the response rate for the data collection of the study was 83.33 percent. Reliability and Explore Factor Analysis (EFA) were used as preliminary analysis for the pilot test. Table 1 illustrated the results of the exploratory factor analysis of the scale items used in the study. After analyzing reliability with Cronbach's Alpha on a final survey, Confirmatory Factor Analysis (CFA) and Structural Equation Model (SEM) were used to achieve the hypothesis testing.

Table 1. Results of Exploratory Factor Analysis.

\begin{tabular}{lcccccccc}
\hline \hline Item & Compo- & Commu- & Item & Compo- & Commu- & Item & Compo- & Commu- \\
& nent 1 & nalities & & nent 2 & nalities & & nent 3 & nalities \\
\hline \hline gov2 & .970 & .829 & str3 & .912 & .884 & per2 & .902 & .800 \\
gov3 & .841 & .774 & str2 & .904 & .896 & per3 & .836 & .796 \\
gov1 & .823 & .654 & str1 & .898 & .844 & per4 & .741 & .741 \\
gov4 & .800 & .774 & str4 & .856 & .847 & per1 & .734 & .667 \\
gov5 & .646 & .667 & & & & per5 & .709 & .637 \\
& & & & & & & & \\
\hline \hline Item & Compo- & Commu- & Item & Compo- & Commu- & Item & Compo- & Commu- \\
& nent 4 & nalities & & nent 5 & nalities & & nent 6 & nalities \\
\hline \hline sid5 & .919 & .697 & so6 & .734 & .676 & cu1 & .880 & .591 \\
sid3 & .806 & .700 & so5 & .725 & .582 & cu3 & .816 & .605 \\
sid1 & .693 & .761 & so2 & .710 & .595 & cu4 & .813 & .752 \\
sid4 & .644 & .689 & so1 & .700 & .584 & cu5 & .678 & .593 \\
sid2 & .520 & .784 & so3 & .669 & .680 & cu6 & .434 & .572 \\
& & & so4 & .601 & .658 & cu7 & .425 & .627 \\
& & & so7 & .562 & .592 & cu1 & .880 & .591 \\
\hline \hline
\end{tabular}


Table 1. Continued.

\begin{tabular}{lllllllll}
\hline \hline Item & $\begin{array}{c}\text { Compo- } \\
\text { nent } 7\end{array}$ & nalities & & nent 8 & nalities & & nent 9 & nalities \\
\hline \hline em2 & .915 & .750 & phy4 & .782 & .793 & acc3 & .931 & .747 \\
$\mathrm{em} 3$ & .884 & .762 & phy1 & .772 & .666 & acc5 & .804 & .644 \\
$\mathrm{em} 5$ & .778 & .629 & phy2 & .767 & .695 & acc2 & .703 & .768 \\
$\mathrm{em} 1$ & .696 & .646 & phy3 & .750 & .720 & acc4 & .577 & .630 \\
$\mathrm{em} 4$ & .678 & .651 & phy5 & .619 & .633 & acc1 & .554 & .714
\end{tabular}

\begin{tabular}{|c|c|c|c|c|c|c|c|c|}
\hline Item & $\begin{array}{l}\text { Compo- } \\
\text { nent } 10\end{array}$ & $\begin{array}{l}\text { Commu- } \\
\text { nalities }\end{array}$ & Item & $\begin{array}{l}\text { Compo- } \\
\text { nent } 11\end{array}$ & $\begin{array}{l}\text { Commu- } \\
\text { nalities }\end{array}$ & Item & $\begin{array}{l}\text { Compo- } \\
\text { nent } 12\end{array}$ & $\begin{array}{l}\text { Commu- } \\
\text { nalities }\end{array}$ \\
\hline ser2 & 8.859 & $\begin{array}{l}.703 \\
\end{array}$ & בide4 & ב.711 & . .664 & $\begin{array}{l}\text { ru4 } \\
\end{array}$ & 8.856 & 2.801 \\
\hline ser1 & .801 & .676 & ide 5 & .701 & .785 & ru3 & .747 & .756 \\
\hline ser3 & .700 & .745 & ide3 & .668 & .774 & $\mathrm{ru} 5$ & .693 & .715 \\
\hline $\operatorname{ser} 5$ & .651 & .747 & ide6 & .636 & .697 & ru2 & .625 & .730 \\
\hline \multirow[t]{2}{*}{ ser 4} & .639 & .756 & ide2 & .601 & .732 & ru1 & .546 & .663 \\
\hline & & & ide1 & .563 & .577 & & & \\
\hline
\end{tabular}

\begin{tabular}{lllllllll}
\hline \hline Item & $\begin{array}{l}\text { Compo- } \\
\text { nent 13 }\end{array}$ & nalities & & nent 14 & nalities & & nent 15 & nalities \\
\hline \hline adv2 & .766 & .855 & id1 & .867 & .748 & sha2 & .808 & .881 \\
adv3 & .649 & .808 & $\mathrm{id} 2$ & .845 & .722 & sha3 & .731 & .821 \\
adv1 & .637 & .825 & $\mathrm{id} 4$ & .699 & .606 & sha1 & .681 & .821 \\
adv4 & .616 & .797 & $\mathrm{id} 3$ & .597 & .526 & & & \\
\hline
\end{tabular}

\section{Measurement instrument}

Scale items of social and non-social CSR such as "the bank participates to the activities which aim to protect and improve the quality of the natural environment," and these of employee CSR such as "the bank's policies encourage the employees to develop their skills and careers" were adapted from Turker (2009) while these of customer CSR such as "the bank protects my rights beyond the legal requirements" and these of government CSR such as "the bank pays its taxes regularly” were measured with items adapted from Maignan et al. (1999); Wagner et al. (2008); Turker (2009); Pérez et al. (2013), and Öberseder et al. (2014) Concerning with corporate image, scale items of corporate identity such as "the name of the bank is recognizable", these of reputation of directors such as "The manner in which the bank is directed is proper" and these of physical 
environment such as "parking facilities of the bank are secured" were adapted from Nguyen (1996) and most of the scale items for service offering such as "the bank provides a variety of financial services", these of contract personnel such as "the staff of the bank is friendly and courteous", these of access to services such as "the waiting time for the financial services of the bank is appropriate" were also adapted from Nguyen (1996) but others were included in these factors such as Evans (1979); Mandel et al. (1981); Yavas et al. (2004), and Flavián et al. (2005). Regarding with loyalty outcomes, scale items of identification such as "the image of the bank is important in deciding to remain a customer" were adopted from Mael and Ashforth (1992) and Ganesh et al. (2000) and these of exclusive consideration such as "the bank is the only one for me to take the financial service" were derived from Hauser and Wernerfelt (1989). Scale items of advocacy such as "I recommend this bank to friends" were measured from Zeithaml (1988), while these of strength of preference such as "I prefer this bank to other banks in getting financial services" were adapted from Mitra and Lynch (1995). The scale items of share of wallet such as "I do all of my banking activities with this bank when I need financial service" were measured from Reynolds and Beatty (1999). The questionnaire for the study consisted of two parts, and the first part was related to demographic factors, including five factors gender, age, occupation, education level, and monthly income of the respondents. The second part was for measurement items that were using five-point Likert scales, ranging from strongly disagree (1) to strongly agree (5).

\section{RESULTS}

According to the finding of the study, the majority were female accounted for $60.4 \%$ and age group between 20 and 30 accounted for $69.04 \%$, and company staff accounted for $38 \%$, and most respondents had been graduated, representing $61 \%$. The income ranged from 150,001 kyats, and 300,000 kyats was received by most of the respondents, accounted for $50 \%$.

This study applied Cronbach's alpha to test scale reliability. The Cronbach's Alpha value of all constructs within the range of 0.758 to 0.940 that was higher than the threshold of 0.7 assured internal consistency of scales (Hair et al. 2009).

A confirmatory factor analysis (CFA) was applied to test the theoretical model and hypothesis. Stakeholder-based CSR included four factors, and these were measured using 22 measurement items. The final model of CFA for CSR was left without reducing any items of CSR to meet the goodness-of-fit GFI (0.95). Corporate image included six factors, and these factors were measured using 28 measurement items. However, in the final CFA model of corporate image, some items were removed to improve model fit-indices and was left 24 items after getting goodnessof-fit GFI that is over 0.95. Loyalty outcomes factors were measured using 22 measurement items. However, some items in the final CFA model were removed to improve model fit-indices and is left 19 items after getting GFI that was over 0.95. In structural equation modeling (SEM), firstly, dependent and independent variables were measured using 72 measurement items. However, some items were removed to improve model fit-indices and is left 31 items as shown in Figure 1 after getting goodness-of-fit GFI that is 0.9. Fit indices of CFA of all variables and SEM were described in Table 2. 
Table 2. Fit indices of CFA for CSR, corporate image, loyalty outcomes, and SEM.

\begin{tabular}{|c|c|c|c|c|c|c|c|c|}
\hline Item & $\begin{array}{c}\text { CMIN } \\
\left(\chi^{2}\right)\end{array}$ & $\begin{array}{l}\text { Degrees } \\
\text { of } \\
\text { freedom } \\
\text { (df) }\end{array}$ & $\begin{array}{c}\text { Probability } \\
\text { level }\end{array}$ & $\begin{array}{l}\chi^{2} \\
/ \mathrm{df}\end{array}$ & GFI & $\begin{array}{c}\text { NNF } \\
\text { I }\end{array}$ & $\overline{\text { CFI }}$ & RMSEA \\
\hline CSR & 259.03 & 210 & 0.000 & 1.23 & 0.95 & 0.99 & 0.99 & 0.02 \\
\hline $\begin{array}{l}\text { Corporate } \\
\text { image }\end{array}$ & 313.17 & 195 & 0.000 & 1.60 & 0.95 & 0.97 & 0.98 & 0.03 \\
\hline $\begin{array}{l}\text { Loyalty } \\
\text { outcome }\end{array}$ & 218.89 & 128 & 0.000 & 1.71 & 0.95 & 0.98 & 0.98 & 0.03 \\
\hline SEM & $1,096.44$ & 415 & 0.000 & 2.64 & 0.90 & 0.92 & 0.92 & 0.05 \\
\hline Fit criteria & - & - & - & $\leq 3$ & $\geq 0.9$ & $\geq 0.9$ & $\geq 0.9$ & $\leq 0.08$ \\
\hline
\end{tabular}

Table 3 presented hypotheses testing with these factors according to SEM output, including six hypotheses in the study. Table 3 indicated acceptance for all these six hypothesized relationships. The standardized regression weights indicated that all these six hypotheses were significant in the hypothesized direction. The antecedents of customer loyalty were corporate image $(\beta=0.741 ; t$-value $=10.973 ; p<0.001)$ and $\operatorname{CSR}(\beta=0.200 ; t-v a l u e=4.586 ; p<0.001)$ All these relationships with customer loyalty show significant; therefore, the hypothesis, namely, $\mathrm{H}_{1}$ and $\mathrm{H}_{2}$ were accepted as shown in Table 3.

Table 3. Hypotheses testing.

\begin{tabular}{lllrrrc}
\hline \hline Path from & $\rightarrow$ to & $\begin{array}{c}\text { Hypo- } \\
\text { thesis }\end{array}$ & $\begin{array}{c}\text { Coeff- } \\
\text { icient }\end{array}$ & $p$ & $\begin{array}{l}\text { C.R } \\
\text { (t-value) }\end{array}$ & $\begin{array}{l}\text { Sup- } \\
\text { ported }\end{array}$ \\
\hline CSR & $\rightarrow$ Customer loyalty & $\mathrm{H}_{1}$ & 0.200 & $0.000^{* * *}$ & 4.586 & YES \\
Corporate Image $\rightarrow$ Customer loyalty & $\mathrm{H}_{2}$ & 0.741 & $0.000^{* * *}$ & 10.973 & YES \\
Customer loyalty $\rightarrow$ Identification & $\mathrm{H}_{3 \mathrm{a}}$ & 0.941 & $0.000^{* * *}$ & & YES \\
Customer loyalty $\rightarrow$ Exclusive Consideration & $\mathrm{H}_{3 \mathrm{~b}}$ & 0.792 & $0.000^{* * *}$ & 8.203 & YES \\
Customer loyalty $\rightarrow$ Advocacy & $\mathrm{H}_{3 \mathrm{c}}$ & 0.892 & $0.000^{* * *}$ & 14.935 & YES \\
Customer loyalty $\rightarrow$ Strength of Preference & $\mathrm{H}_{3 \mathrm{~d}}$ & 0.906 & $0.000^{* * *}$ & 15.415 & YES \\
Customer loyalty $\rightarrow$ Share of Wallet & $\mathrm{H}_{3 \mathrm{e}}$ & 0.750 & $0.000^{* * *}$ & 12.162 & YES \\
\hline \hline Note: ${ }^{* *}$ Significant level at $p<0.001$ & & & & &
\end{tabular}


The relationship between customer loyalty and exclusive consideration was $(\beta=0.792 ; \mathrm{t}$ value=8.203; $p<0.001$ ), thus, supporting $\mathrm{H}_{3 \mathrm{~b}}$. The relationship between customer loyalty and advocacy was $(\beta=0.892$; $t$-value $=14.935 ; p<0.001)$ and it supported $\mathrm{H}_{3 c}$. The relationship between customer loyalty and strength of preference was $(\beta=0.906 ; t$-value $=15.415 ; p<0.001)$, thus, supporting $\mathrm{H}_{3 \mathrm{~d}}$. Moreover, the relationship between customer loyalty and share of wallet was $(\beta=0.750 ; t$-value $=12.162 ; p<0.001)$ and it is supported $\mathrm{H}_{3 \mathrm{e}}$. Besides, the relationship between customer loyalty and identification was also supported.

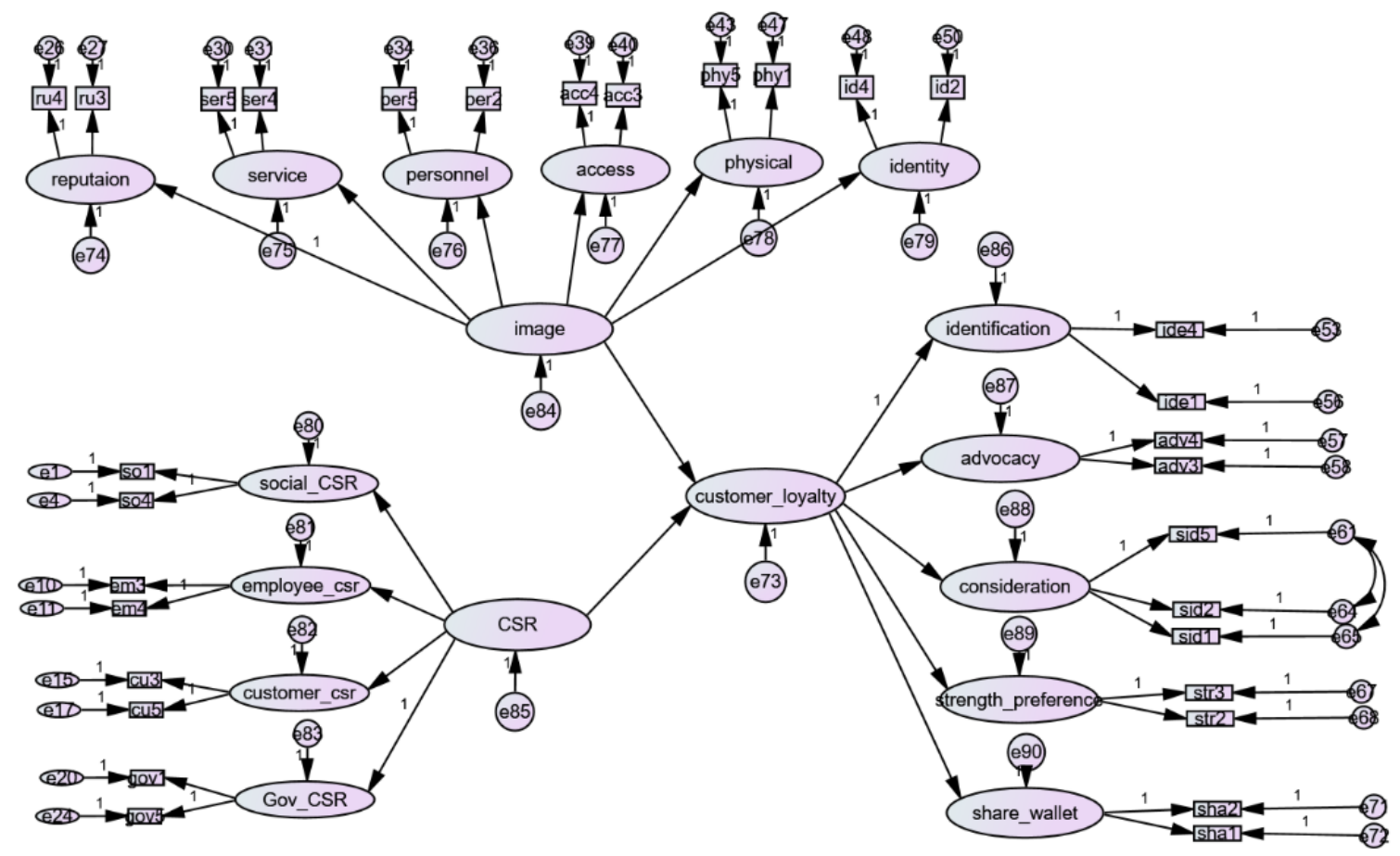

Figure 1. Final model of SEM with standardized beta coefficient.

\section{DISCUSSION}

Customers are one of the relevant stakeholder groups that are most affected by an organization's activities (Freeman, 1984). Moisescu (2017c) found that CSR had a significant impact on customer loyalty in retail banking of a developing country - Romania, being consistent with the finding of the current study. Servera-Francés and Piqueras-Tomás (2019) also described that CSR activities were positively related to customer loyalty through customer perceived value in other retail industries.

Many studies supported that corporate image had an impact on customer loyalty in service sectors (Kim \& Lee, 2010, de Leaniz \& del Bosque, 2016). However, some researches argued that corporate image had no a direct effect on customer loyalty in the travel industry (Richard \& Zhang, 2012) and the same finding came out in Turkish mobile telecommunication context (Aydin \& Özer, 2005), not supporting the relationship between corporate image and customer loyalty. In the present study, corporate image represented a predictor of customer loyalty of banking customers. This finding was in line with previous researches in the banking sector - indicating that corporate image had a positive impact on customer loyalty (Darmawan et al., 2017, Al-Areqi et al., 2018, Kant et al., 2019) 
Customer loyalty had a positive impact on identification, exclusive consideration, advocacy, the strength of preference, and share of wallet of banking customers in Myanmar. This finding was consistent with the previous one, that the level of customer loyalty influenced these loyalty outcomes, according to Bourdeau (2005). Kang et al. (2015) founded that loyalty program had a direct impact on identification and share of wallet. According to Jones and Taylor (2012), identification, exclusive consideration, advocacy, the strength of preference, and share of wallet were outcomes of loyal customers.

\section{Theoretical contribution}

The aim of this study was to analyze the impact of CSR and corporate image on customer loyalty and to explore the relationship between customer loyalty and loyalty outcomes of banking customers in Myanmar. Most previous research regarding CSR did not focus on stakeholder, but this study emphasized stakeholder-based theory to predict customer loyalty. Concerning with CSR and corporate image, the study was used each component of these variables to analyses their impact on customer loyalty. Therefore, the finding of the study was significant by describing the impact of each component of CSR and corporate image on customer loyalty. The study also found out the impact of customer loyalty on loyalty outcomes. Therefore, the study contributed significantly to the marketing literature by focusing on the antecedents and consequences of customer loyalty.

Another contribution was the new combination of CSR, corporate image, customer loyalty, and loyalty outcomes in the marketing context, especially for consumer behaviors such as repurchase or word-of-mouth. Most of the previous researches on stakeholder CSR and corporate image were emphasized in developed countries so that the study was contributed to the CSR and corporate image theoretical aspect for developing countries in the service industries, specifically banking service.

\section{Managerial implication}

This study offered a deeper understanding of the influence of CSR activities on customer loyalty, indicating outcomes of loyal customers. It is found that the companies which focused on stakeholder attitude in business functions perform better than those that do not (Polonsky \& Scott, 2005). According to the finding of the study, the customers' perception of CSR to customers can affect their loyalty conditions rather than other CSR components. Therefore, it is needed to respect the right of customers and to conduct fairly and focus on the need of the customers. It is also necessary for the company to communicate its CSR activities to customers to have a favorable response from them.

The company directors need to maintain their reputation by doing credible action and providing significant benefits for customers. The company needs to do the vital factors for customers, including that the waiting time and operating time are proper for banking customers and making that the services are easy to use when the customers need. To make the customers more access to bank services, the company should open more bank branches and set up more ATMs in the crowded areas and major markets. Also, it needs to do a parking facility, the good environment, and proper layout to be appropriate for customers. In supporting these things, the customers are loyal, and they identify themselves as their consumers, consider only this company, prefer it more and tell others the good things of the company.

\section{LIMITATIONS AND RECOMMENDATIONS FOR FUTURE RESEARCH}


Although the results of the present research are significant, few limitations in the study show scopes for future research. The first limitation associated with the generalizability of the results. The study was collected a large sample data, but it was only focused on the banking customers of a major bank in Myanmar. The second limitation was that the study was used CSR and corporate image to predict customer loyalty, but there might be other factors that affect customer loyalty, such as trust, service quality.

According to the limitations of the study, there are several needs for further research. In order to predict the customer loyalty of the service industry, it is needed to collect data from several service industries such as Telecom and Beauty Sloon. The study can be extended by adding other variables or mediators, such as brand trust and service quality to predict the loyalty of banking customers better. The study in different developing countries like Myanmar such as Thailand, Cambodia might compare the analysis result to explore the different perceptions of customers on CSR, corporate image, and customer loyalty.

\section{ACKNOWLEDGEMENTS}

This research report in the paper was undertaken as part of MBA study at International Colleague, Panyapiwat Institute of Management, in Thailand. The authors would like to acknowledge the contributions of the respondents who were asked with structured questionnaire about banking services in Myanmar.

\section{REFERENCES}

Ailawadi, K.L., Neslin, S.A., Luan, Y.J., \& Taylor, G.A. (2014). Does retailer CSR enhance behavioral loyalty? A case for benefit segmentation. International Journal of Research in Marketing, 156-167. https://doi.org/10.1016/j.ijresmar.2013.09.003

Al-Areqi, B., Al-Hadheq, A., \& Mutahar, A. (2018). Determinants of customer loyalty in Yemen banking industry. Journal of Business and Management, 20(9), 1-12. https://doi.org/ 10.9790/487X-2009070112

Ali, R., Leifu, G., \& Rehman, R. (2014). Factors influencing customer loyalty of banking industry: empirical evidence from Pakistan. International Journal of Learning and Development, 4(2), 9-26. https://doi.org/10.5296/ijld.v4i2.5029

Andreassen, T.W., \& Lindestad, B. (1998). The effect of corporate image in the formation of customer loyalty. Journal of Service Research, 1(1), 82-92. https://doi.org/10.1177/ 109467059800100107

Aydin, S., \& Özer, G. (2005). The analysis of antecedents of customer loyalty in the Turkish mobile telecommunication market. European Journal of Marketing, 39(7/8), 910-925. https://doi.org/10.1108/03090560510601833

Bakar, J.A., Clemes, M.D., \& Bicknell, K. (2017). A comprehensive hierarchical model of retail banking. International Journal of Bank Marketing, 35(4). https://doi.org/10.1108/IJBM03-2016-0041

Balmer, J.M., Abratt, R., \& Nsenki Mofokeng, T. (2001). Development and management of corporate image in South Africa. European Journal of Marketing, 35(3), 368-386. https://doi.org/10.1108/03090560110382075 
Barkemeyer, R., \& Miklian, J. (2019). Responsible business in fragile contexts: comparing perceptions from domestic and foreign firms in Myanmar. Sustainability, 11(3), 598. https://doi.org/10.3390/su11030598

Bhattacharya, C.B., Rao, H., \& Glynn, M.A. (1995). Understanding the bond of identification: an investigation of its correlates among art museum members. Journal of Marketing, 59(4), 46-57. https://doi.org/10.2307/1252327

Bourdeau, B.L. (2005). A new examination service loyalty: identificaiton of antecentent and outcomes of an attitudinal loyalty framework. (Doctoral dissertation) Florida State University. USA.

Butcher, K., \& Chomvilailuk, R. (2014). Effects of quality and corporate social responsibility on loyalty. Service Industries Journal, 34(11),938-954. https://doi.org/10.1080/02642069.20 14.915952

Butcher, K., Sparks, B., \& O'Callaghan, F. (2001). Evaluative and relational influences on service loyalty. International Journal of Service Industry Management, 12(4), 310-327.

Castelo, B.M. (2013). Banks and CSR. In S.O. Idowu, N. Capaldi, L. Zu, \& A.D. Gupta, Encyclopedia of Corporate Social Responsibility (pp. 141-147). New Orleans: Springer .

Carroll, A.B. (1979). A three-dimensional conceptual model of corporate performance. The Academy of Management Review, 10(4), 497-505. https://doi.org/10.2307/257850

Chaudhuri, A., \& Holbrook, M.B. (2001). The chain of effects from brand trust and brand affect to brand performance: the role of brand loyalty. Journal of Marketing, 65(2), 81-93 https://doi.org/10.1509/jmkg.65.2.81.18255

Chung, K.-H., Yu, J.-E., Choi, M.-G., \& Shin, J.-I. (2015). The effects of CSR on customer satisfaction and loyalty in China: the moderating role of corporate image. Journal of Economics, Business and Management, 3(5), 542-547. https://doi.org/10.7763/JOEBM. 2015.V3.243

Darmawan, D., Mardikaningsih, R., \& Hadi, S. (2017). The effect of service quality, customer satisfaction and corporate image on customer loyalty in the banking sector in Indonesia. Journal of Business and Management, 19(11), 46-51. https://doi.org/10.9790/487X1911064651

Day, G.S. (1969). A two - dimensional concept to brand loyalty. Journal of Advertising Research, 9(3), 29-35.

de Leaniz, P.M., \& del Bosque, R.I. (2016). Corporate image and reputation as drivers of customer loyalty. Corporate Reputation Review, 19(2), 166-178. https://doi.org/10.1057/crr.2016.2

Dichter, E. (1985). What's in an image. Journal of Consumer Marketing, 2(1), 75-81. https://doi.org/10.1108/eb038824

Dick, A.S., \& Basu, K. (1994). Customer loyalty: toward an integrated conceptual framework. Journal of the Academy of Marketing Science, 22(2), 99-113. https://doi.org/10.1177/ 0092070394222001

Dwyer, F.R., Schurr, P.H., \& Oh, S. (1987). Developing buyer-seller relationship. Journal of Marketing, 51(2), 11-27. https://doi.org/10.2307/1251126

Evans, R. (1979). Bank selection: it all depends on the situation. Journal of Bank Research, 242247.

Evanschitzky, H., Ramaseshan, B., Woisetschläger, D.M., Richelsen, V., Blut, M., \& Backhaus, C. (2012). Consequences of customer loyalty to the loyalty program and to the company. Journal of the Academy of Marketing Science, 40(5), 625-638. https://doi.org/ $10.1007 / \mathrm{s} 11747-011-0272-3$ 
Fatma, M., Rahman, Z., \& Khan, I. (2014). Multi-item stakeholder based scale to measure CSR in the banking industry. International Strategic Management Review, 2(1), 9-20. https:// doi.org/10.1016/j.ism.2014.06.001

Flavián, C., Guinalíu, M., \& Torres, E. (2005). The influence of corporate image on consumer trust: a comparative analysis in traditional versus internet banking. Internet Research, 15(4), 447-470. https://doi.org/10.1108/10662240510615191

Freeman, R.E. (1984). Strategic management: a stakeholder approach. Boston: Pitman Publishing.

Freeman, R.E., Harrison, J.S., Wicks, A.C., Parmar, B.L., \& Colle, S.d. (2010). Stakeholder theory: the state of the art. UK: Cambridge University Press.

Gabbott, M., \& Hogg, G. (1994). Consumer behaviour and services: a review. Journal of Marketing Management, 10(4), 311-324. https://doi.org/10.1080/0267257X.1994.9964277

Ganesh, J., Arnold, M.J., \& Reynolds, K.E. (2000). Understanding the customer base of service providers: an examination of the differences between switchers and stayers. Journal of Marketing, 64(3), 65-87. https://doi.org/10.1509/jmkg.64.3.65.18028

Gioia, D.A., Schultz, M., \& Corley, K.G. (2000). Organizational identity, image, and adaptive instability. The Academy of Management Review, 25(1), 63-81. https://doi.org/10.2307/ 259263

Greve, G. (2014). The moderating effect of customer engagement on the brand image - brand loyalty relationship. Procedia - Social and Behavioral Sciences, 148, 203-210. https://doi. org/10.1016/j.sbspro.2014.07.035

Hair, J.F., Black, W.C., Babin, B.J., \& Anderson, R.E. (2009). Multivariate Data Analysis (7th ed.). Harlow: Prentice Hall.

Hall, R. (1993). A framework linking intangible resources and capabiliites to sustainable competitive advantage. Strategic Management Journal, 14(8), 607-618. https://doi.org/10. $1002 /$ smj. 4250140804

Härtel, C.E., \& Russell-Bennett, R. (2010). Heart versus mind: the functions of emotional and cognitive loyalty. Australasian Marketing Journal, 18(1), 1-7. https://doi.org/10.1016/ j.ausmj.2009.10.003

Hauser, J.R., \& Wernerfelt, B. (1989). The competitive implications of relevant-set/response analysis. Journal of Marketing Research, 26(4), 391-405. https://doi.org/10.2307/3172760

Homburg, C., Müller, M., \& Klarmann, M. (2011). When should the customer really be King? on the optimum level of salesperson customer orientation in sales encounters. Journal of Marketing, 75(2), 55-74. https://doi.org/10.1509/jm.75.2.55

Ibáñez, V.A., Hartmann, P., \& Calvo, P.Z. (2006). Antecedents of customer loyalty in residential energy markets: service quality, satisfaction, trust and switching costs. The Service Industries Journal, 26(6), 633-650. https://doi.org/10.1080/02642060600850717

Iqbal, M., \& Pramanik, S.A. (2017). Investigating the impacts of CSR initiatives on customers' loyalty: a study from selected private banks in Bangladesh. Daffodil International University Journal of Business and Economics, 10(1), 1-18.

Javalgi, R., \& Moberg, C.R. (1997). Service loyalty: implications for service providers. Journal of Services Marketing, 11(3), 165-179.

Jones, T., \& Taylor, S.F. (2007). The conceptual domain of service loyalty: how many dimensions? Journal of Services Marketing, 21(1), 36-51. https://doi.org/10.1108/08876040710726284

Jones, T., \& Taylor, S.F. (2012). Service loyalty: accounting for social capital. Journal of Services Marketing, 26(1), 60-75. https://doi.org/10.1108/08876041211199733 
Kandampully, J., Zhang, T., \& Bilgihan, A. (2015). Customer loyalty: a review and future directions with a special focus on the hospitality industry. International Journal of Contemporary Hospitality Management, 27(3), 379-414. https://doi.org/10.1108/IJCHM03-2014-0151

Kang, J., Alejandro, T.B., \& Groza, M.D. (2015). Customer-company identification and the effectiveness of loyalty programs. Journal of Business Research, 68, 464-471. https://doi.org/ 10.1016/j.jbusres.2014.06.002

Kant, R., Jaiswal, D., \& Mishra, S. (2019). A model of customer loyalty: an empirical study of Indian retail banking customer. Global Business Review, 20(5), 1-19.

Keisidou, E., Sarigiannidis, L., Maditinos, D.I., \& Thalassinos, E.I. (2013). Customer satisfaction, loyalty and financial performance. International Journal of Bank Marketing, 31(4), 259288. https://doi.org/10.1108/IJBM-11-2012-0114

Kennedy, S.H. (1977). Nurturing corporate images. European Journal of Marketing, 11(3), 120164. https://doi.org/10.1108/EUM0000000005007

Kim, Y.-E., \& Lee, J.-W. (2010). Relationship between corporate image and customer loyalty in mobile communications service markets. Africa Journal of Business Management, 4(18), 4035-4041.

Kolk, A., \& Tulder, R.v. (2010). International business, corporate social responsibility and sustainable development. International Business Review, 19(2), 119-125.

Kotler, P., \& Lee, N. (2005). Corporate social responsibility: doing the most good for your company and your cause. New Jersey: John Wiley \& Sons, Inc.

Lee, C.-Y. (2018). Does corporate social responsibility influence customer loyalty in the Taiwan insurance sector? The role of corporate image and customer satisfaction. Journal of Promotion Management, 25(1),1-22. https://doi.org/10.1080/10496491.2018.1427651

Leninkumar, V. (2017). The relationship between customer satisfaction and customer trust on customer Loyalty. International Journal of Academic Research in Business and Social Sciences, $7(4), 450-465$.

Lewis, B.R., \& Soureli, M. (2006). The antecedents of consumer loyalty in retail banking. Journal of Consumer Behaviour, 5(1), 15-31. https://doi.org/10.1002/cb.46

Liat, C.B., Mansori, S., Chuan, G.C., \& Imrie, B.C. (2017). Hotel service recovery and service quality: influences of corporate image and generational differences in the relationship between customer satisfaction and loyalty. Journal of Global Marketing, 30(1), 42-51. https://doi.org/10.1080/08911762.2016.1262932

Lombart, C., \& Louis, D. (2014). A study of the impact of corporate social responsibility and price image on retailer personality and consumers' reactions (satisfaction, trust and loyalty to the retailer). Journal of Retailing and Consumer Services, 21(4), 630-642. https://doi.org/ 10.1016/j.jretconser.2013.11.009

Mael, F., \& Ashforth, B.E. (1992). Alumni and their alma mater: A partial test of the reformulated model of organizational identification. Journal of Organizational Behavior, 13(2), 103-123. https://doi.org/10.1002/job.4030130202

Maignan, I., Ferrell, O.C., \& Hult, G.T. (1999). Corporate citizenship: cultural antecedents and business benefits. Journal of the Academy of Marketing Science, 27(4), 455-469. https://doi.org/10.1177/0092070399274005 
Makanyeza, C., \& Chikazhe, L. (2017). Mediators of the relationship between service quality and customer loyalty: evidence from the banking sector in Zimbabwe. International Journal of Bank Marketing, 35(3). https://doi.org/10.1108/IJBM-11-2016-0164

Mandel, L., Lachman, R., \& Orgler, Y. (1981). Interpreting the image of banking. Journal of Bank Research, 12(2), 96-104.

Melewar, T. (2008). Facets of corporate identity, communication and reputation. New York: Routledge.

Minyin, Z. (2018, May 3). Myanmar's top 4 companies for sustainability and CSR. Retrieved from prospects: https://www.prospectsasean.com/myanmar-top-4-companies-for-sustainabilitycsr/

Mitra, A., \& Lynch, J.G. (1995). Toward a reconciliation of market power and information theories of advertising effects on price elasticity. Journal of Consumer Research, 21(4), 644659. https://doi.org/10.1086/209425

Moisescu, O.-I. (2017c). From CSR to customer loyalty: an empirical investigation in the retail banking industry of a developing country. Scientific Annals of Economics and Business, 64(3), 307-323. https://doi.org/10.1515/saeb-2017-0020

Mokhtar, S.S., Maiyaki, A.A., \& Noor, N.B. (2011). The relationship between service qualityand satisfaction on customer loyalty in malaysian mobile communication industry. School of Doctoral Studies (European Union) Journal, 32-38.

Myint, N.Z., \& Kohsuwan, P. (2019). Determining customer loyalty outcomes through corporate social responsibility (CSR) and customer-based brand. APHEIT International Journal, $8(2), 64-86$.

Nguyen, G.L. (1996). Cues used by customers evaluating corporate image in service firms: an empirical study in financial institutions. International Journal of Service Industry Management, 7(2), 44-56. https://doi.org/10.1108/09564239610113460

Öberseder, M., Schlegelmilch, B.B., Murphy, P.E., \& Gruber, V. (2014). Consumers' perceptions of corporate social responsibility: scale development and validation. 124(1), 101-115. https://doi.org/10.1007/s10551-013-1787-y.

Oliver, R.L. (1999). Whence consumer loyalty? American Marketing Association, 63, 33-44.

Osman, I., Alwi, S.F., Mokhtar, I., Ali, H., Setapa, F., Muda, R., \& Rahim, A.R. (2015). Integrating institutional theory in determining corporate image of Islamic banks. Islamic Banks, 211, 560-567. https://doi.org/10.1016/j.sbspro.2015.11.074

Oxford Business Group. (2019). The Report: Myanmar 2019. Oxford Business Group. Retrieved from https://oxfordbusinessgroup.com/myanmar-2019/financial-services

Pan, Y., Sheng, S., \& Xie, F.T. (2012). Antecedents of customer loyalty: an empirical synthesis and reexamination. Journal of Retailing and Consumer Services, 19(1), 150-158. https:// doi.org/10.1016/j.jretconser.2011.11.004

Pérez, A., Salmones, d.M., \& Bosque, R.d. (2013). The effect of corporate associations on consumer behaviour. European Journal of Marketing, 47(1/2), 218-238. https://doi.org/ $10.1108 / 03090561311285529$

Polonsky, M.J., \& Scott, D. (2005). An empirical examination of the stakeholder strategy matrix. European Journal of Marketing, 39(9/10), 1199-1255.

Prus, A., \& Brandt, D.R. (1995). Understanding your customers. Marketing Tools, 2(5), 10-14. 
Rad, H.S., Rasoulian, A., Mirzaei, M., \& Sharifipour, A. (2017). Electronic banking; a new strategy to create customers' loyalty to investment and its impacton economic initiatives. International Journal of Management, Accounting and Economics, 4(4), 431-442.

Rai, A.K. (2013). Customer relationship Management: concepts and cases (2nd ed.). New Delhi: PHI Learning Private Limited.

Rai, A.K., \& Srivastava, M. (2012). Customer loyalty attributes: a perspective. NMIMS Management Review, 22, 49-76.

Rai, A.K., \& Srivastava, M. (2014). Customer loyalty: concept, context and character. New Delhi: McGraw Hill Education Priate Limited.

Reynolds, K.E., \& Beatty, S.E. (1999). A relationship customer typology. Journal of Retailing, 75(4), 509-523. https://doi.org/10.1016/S0022-4359(99)00016-0

Richard, J.E., \& Zhang, A. (2012). Corporate image, loyalty, and commitment in the consumer travel industry. Journal of Marketing Management, 28(5-6), 568-593. https://doi.org/10. 1080/0267257X.2010.549195

Schmitt, B.H., \& Pan, Y. (1994). Managing corporate and brand identities in the Asia-Pacific Region. California Management Review, 36(4), 32-48.https://doi.org/10.2307/41165765

Seiler, V., Rudolf, M., \& Krume, T. (2013). The influence of socio-demographic variables on customer satisfaction and loyalty in the private banking industry. International Journal of Bank Marketing, 31(4), 235-258.

Servera-Francés, D., \& Piqueras-Tomás, L. (2019). The effects of corporate social responsibility on consumer loyalty through consumer perceived value. Economic Research, 32(1), 66-84. https://doi.org/10.1080/1331677X.2018.1547202

Singh, I., Nayyar, A., \& Das, S. (2019). A study of antecedents of customerloyalty in banking \& insurance sectorand their impact on business performance. Revista ESPACIOS, 40(6), 112

So, K.K., KIng, C., Sparks, B.A., \& Wang, Y. (2013). The influence of customer brand identification on hotel brand evaluation and loyalty development. International Journal of Hospitality Managment, 34, 31-31. https://doi.org/10.1016/j.ijhm.2013.02.002

Solomon, M.R. (1985). Packaging the service provider. Service Industries Journal, 5(1), 64-72. https://doi.org/10.1080/02642068500000006

Telagawathi, N.L., Mayasari, N.M., \& Yulianthini, N.N. (2018). Customer satisfaction on company image and its impact on loyalty of banking service industry customers in Bali. $3^{\text {rd }}$ International Conference on Tourism, Economics, Accounting, Management, and Social Science. 69, pp. 16-20. Atlantis Press.

Turker, D. (2009). Measuring corporate social responsibility: a scale development study. Journal of Business Ethics, 85, 411-427. https://doi.org/10.1007/s10551-008-9780-6

Valipour, A., Noraei, M., \& Kavosh, K. (2018). A meta-analysis of customer loyalty in the banking Services. ASEAN Marketing Journal, 8(2), 137-155.

Wagner, T., Bicen, P., \& Hall, Z.R. (2008). The dark side of retailing: towards a scale of corporate social irresponsibility. International Journal of Retail and Distribution Management, 36(2), 124-142. https://doi.org/10.1108/09590550810853075

Wang, L., \& Chaipoopirutana, S. (2014). The influence of perceived service quality, corporate image, customer satisfaction and value on customer loyalty of agriculture bank of China in Kunming, China. International Conference on Trends in Economics, Humanities and Management (pp. 172-176). Pattaya: ICTEHM. 
Westbrook, R.A. (1987). Product/consumption-based affective responses and postpurchase processes. Journal of Marketing Research, 24(3), 258-270. https://doi.org/10.2307/315 1636

World Bank. (2018, September 21). Number of bank accounts for Myanmar. Retrieved from https://fred.stlouisfed.org/series/DDAI01MMA642NWDB

Yavas, U., Benkenstein, M., \& Stuhldreier, U. (2004). Relationships between service quality and behavioral outcomes. International Journal of Bank Marketing, 22(2), 144-157. https://doi. org/10.1108/02652320410521737

Yunus, N.A., Rahman, B.A., \& Othman, A.K. (2012). The relationship between service quality and customer loyalty at a telecommunication company in Malaysia. International Conference on Innovation Management and Technology Research (ICIMTR), (pp. 39-44). Malacca.

Zeithaml, V.A. (1988). Consumer perceptions of price, quality, and value: a means-end model and synthesis of evidence. Journal of Marketing, 52(3), 2-22. https://doi.org/10.1177/00222 4298805200302 